\title{
BUDAYA BIROKRASI DALAM MEWUJUDKAN GOOD GOVERNANCE DI SEKRETARIAT DAERAH PROVINSI KALIMANTAN TENGAH
}

\author{
Bureaucratic Culture Realizing Good Governance \\ in the Regional Secretariat of Central Kalimantan Province
}

\section{Oktipia Pengestika' \\ Bulkani $^{2}$ \\ Novianto Eko Wibowo ${ }^{3}$}

Universitas Muhammadiyah Palangkaraya, Palangka Raya, Central Kalimantan, Indonesia

email: oktipia@gmail.com

\section{Kata Kunci:}

Budaya

Birokrasi

Pemerintahan

\section{Keywords:}

Culture

Bureaucracy

Government

\section{Accepted}

Januari 2020

\section{Published}

April 2020

\begin{abstract}
Abstrak
Tujuan penelitian ini untuk mengetahui dan menggambarkan budaya birokrasi dalam mewujudkan good governance di Sekretariat Daerah Provinsi Kalimantan Tengah. Serta menyusun strategi budaya birokrasi di Sekretariat Daerah Provinsi Kalimantan Tengah dalam mewujudkan good governance.

Penelitian ini menggunakan pendekatan kualititatif. Data penelitian ini diperoleh dari hasil pengamatan langsung, wawancara, dan mengumpulkan dokumendokumen. Adapun informan dalam penelitian ini adalah pejabat dan staf di Sekretariat Daerah yang dianggap relevan dan berkompeten terkait dalam penyelenggaraan budaya birokrasi di Sekretariat Daerah.

Hasil penelitian menunjukkan bahwa Budaya Birokrasi Pemerintahan di Sekretariat Daerah Provinsi Kalimantan Tengah saat ini masih terjebak ke dalam budaya birokrasi statis mekanistis, budaya birokrasi patologis dan budaya birokrasi aristokrat, sehingga sangat berpengaruh besar terhadap kinerja birokrasi dalam mewujudkan Good Governance. Saran yang dapat diberikan oleh peneliti yakni pimpinan organisasi birokrasi untuk mempunyai visi dan misi yang jelas dan dapat menjadi contoh teladan yang baik bagi bawahannya serta memiliki komitmen yang kuat dalam mewujudkan budaya birokrasi yang dibutuhkan organisasi. Dengan terlebih dahulu mendiagnosa budaya yang ada ditubuh birokrasi.
\end{abstract}

\begin{abstract}
The purpose of this research is to know and describe the bureaucratic culture in realizing good governance in the regional secretariat of central Kalimantan province. As well as to develop the bureaucratic cultural strategy in the Regional secretariat of central Kalimantan province in realizing good governance.

The study used a qualitative approach. The research data is derived from live observations, interviews, and collecting documents. The informant in this research is the official and staff in the regional secretariat which considered relevant and competent related in organizing the bureaucratic culture in the regional secretariat.

The results showed that the government bureaucracy culture in the central Kalimantan provincial secretariat is still trapped into the mechanistic static bureaucratic culture, the pathological bureaucracy and cultural bureaucratic bureaucracies, so Great influence on bureaucracy performance in realizing Good Governance. Advice that can be given by researchers is the leader of bureaucracy organization to have a clear vision and mission and can be an example of good examples for his subordinates and has a strong commitment to realizing the bureaucratic culture needed Organization. By first diagnose the culture that there is written bureaucracy.
\end{abstract}




\section{PENDAHULUAN}

Pemerintah saat ini dengan gencarnya melakukan perubahan struktur, fungsi, finansial dan personalia dari organisasi birokrasi itu, tetapi sesungguhnya yang terpenting perlu digaris bawahi bahwa perubahan tersebut di atas harus diikuti perubahan budaya birokrasi dan perilaku manusiamanusia yang telibat di dalamnya.

Birokrasi, sebagaimana organisasi lainnya yang tidak lepas dari pengaruh lingkungan dan budaya, dalam aktifitasnya juga terlibat secara intensif melalui polapola interaksi yang terbentuk didalamnya dengan system nilai dan budaya lokal. Budaya birokrasi yang berkembang disuatu daerah tertentu, misalnya tidak terlepas dari pola budaya lingkungan sosial yang melingkupinya.

Terselengaranya pemerintahan yang baik, bersih dan berwibawa (clean and good governance) menjadi cita-cita dan harapan setiap bangsa. Agar penyelenggaraan pemerintah tidak menjurus kepada kediktatoran, maka diperlukannya sistem saling mengawasi dan saling mengimbangi (checks and balance) antar lembaga tinggi negara, inilah yang disebut checking power with power.

Namun pada kenyataanya sekarang walaupun sistem sudah tertata dengan baik, tetapi masih banyak saja yang ditemukan tindakan-tindakan yang menyimpang (deviate) oleh unsur pelaksana negara (birokrat).

Media cetak dan media elektronik yang ada di Indonesia baik tingkat nasional maupun tingkat lokal gencar menyoroti lembaga-lembaga pemerintah yang diduga melakukan melakukan tindakan penghianatan amanat rakyat berupa praktik-praktik korupsi, nepotisme, dan kolusi (KKN), serta buruknya pelayanan pemerintah (public service). Saat ini para pejabat negara yang ada di republik ini telah banyak yang dijerat oleh hukum dikarenakan melakukan praktek-praktek kotor tersebut, sehingga menimbulkan kerugian negara milyaran dan bahkan sampai triliunan rupiah.

Kritikan bahkan sampai teriakan, hujatan dan makian pada demonstran yang sering disuarakan oleh para mahasiswa, LSM dan ormas kepada pemerintah nampaknya tidak begitu berarti untuk mengubah pola sikap perilaku dan tindakan para birokrat pemerintah yang tidak sesuai dengan prinsip atau nilai-nilai dasar penyelenggaraan pemerintahan yang baik (good governance). Apabila hal ini terus berlanjut dikhawatirkan akan dapat merusak salah satu unsur modal sosial (sosial capital) yakni rasa kepercayaan (trust) masyarakat terhadap semua kebijakan pemerintah. Gejala rasa ketidak percayaan masyarakat ini sudah mulai dapat dirasakan saat ini.

Undang-undang Nomor 23 Tahun 2014 tentang Pemerintahan Daerah telah memberikan saluran baru bagi pemerintah Provinsi Kalimantan Tengah untuk mengambil tanggung jawab yang besar dalam pelayanan umum kepada masyarakat setempat, untuk mengatur dan mengurus rumah tangganya sendiri. Misi utama dari keberadaan pemerintah daerah adalah bagaimana mensejahterakan masyarakat melalui penyediaan pelayanan publik secara efektif, efisien dan ekonomis serta melalui cara-cara demokratis (Suwandi, 2003).

Pemerintah Daerah Provinsi Kalimantan Tengah dalam menjalankan fungsi pemerintahan yang tergambar dalam suatu tatanan struktur formil dan dideskripsikan kedalam tugas pokok dan fungsi masingmasing aparatur pemerintah daerah. Dalam pemberian pelayanan kenyataannya pelayanan yang diberikan masih relatif kurang memuaskan. Proses pembuatannya masih terlalu lama dengan tidak memiliki kepastian waktu, harga yang relatif mahal. Permasalahan tersebut terjadi karena masih banyaknya oknum pegawai yang tidak bertanggung jawab dengan menaikan harga administrasi pelayanan dengan alasan biaya fotokopi, transport atau biaya cepat atau lambat serta sikap 
pegawai yang tidak ramah dalam memberikan pelayanan.

Pemerintah belum menaruh perhatian yang serius terhadap perubahan budaya birokrasi pemerintahan. Ini terlihat pada anggaran Pemerintah Daerah Provinsi Kalimantan Tengah yang belum berpihak pada pembangunan non fisik yaitu SDM itu sendiri, justru telalu berfokus pada pembangunan fisik seperti pembangunan jembatan, gedung, jalan dan lainlain. Sebenarnya budaya birokrasi sangat penting pengaruhnya terhadap keberhasilan tehadap sebuah organisasi.

Penataan struktur organisasi birokrasi pun tidak akan bedampak besar terhadap pemerintahan apabila tidak didukung oleh budaya birokrasi yang ideal, good governance akan tercapai apabila kedua-duanya saling mendukung.

Pemahaman para birokrat mengenai tugas dan fungsi saja tidaklah cukup, mereka harus memiliki niat baik (good will), kemauan disertai dengan pelaksanaan yang sesuai dengan mekanisme yang jelas untuk mewujudkan suatu kepemerintahan yang baik (good governance). Terselenggaranya kepemerintahan yang baik, bersih dan berwibawa (clean and good governance) menjadi cita-cita dan harapan suatu bangsa.

Dalam wujud Good Governance menuntut keterlibatan seluruh elemen yang ada dalam masyarakat. Hal ini dapat diwujudkan manakala pemerintah didekatkan dengan yang diperintah. Pemerintah yang didekatkan dengan yang diperintah berarti desentralisasi dan Otonomi Daerah. Menurut Drucker dalam Sadu Wasistiono (2002:40) mengatakan bahwa kemajuan suatu negara akan sangat ditentukan oleh kualitas manajemennya karena ketertinggalan dalam manajemennya (undermanaget country). Birokrasi pemerintahan tidak menjadi kompeten dan profesional, apabila pemerintah tidak segera melakukan perubahan menuju birokrasi pemerintahan yang baik. Hal inilah yang mendorong peneliti untuk mengadakan penelitian dengan judul
"Budaya Birokrasi dalam Mewujudkan Good Governance di Sekretariat Daerah Provinsi Kalimantan Tengah".

\section{METODOLOGI}

Penelitian yang digunakan untuk menganalisis budaya birokrasi di Sekretariat Daerah Provinsi Kalimantan Tengah adalah penelitian kualitatif dengan penelitian studi kasus. Hal tersebut merujuk dengan pendapat Rusidi (2003:10) mengemukakan bahwa penelitian case study merupakan penelitian yang bersifat eksplorasi mendalam tapi tidak meluas dengan tujuan untuk memperoleh deskripsi fenomena khusus, konkrit dan lokus. Sejalan dengan hal tersebut, maka penelitian menggunakan penelitian kualitatif dengan pola pendekatan studi kasus, yang dalam penelitian deskriptif melakukan pengukuran secara cermat gejala sosial tertentu dengan menghimpun fakta serta tidak melakukan pengujian hipotesis, dan mencari gambaran pasti.

Data penelitian ini diperoleh dari hasil pengamatan langsung, wawancara, dan mengumpulkan dokumen-dokumen. Adapun informan dalam penelitian ini adalah pejabat dan staf di Sekretariat Daerah yang dianggap relevan dan berkompeten terkait dalam penyelenggaraan budaya birokrasi di Sekretariat Daerah seperti Kepala Biro umum, Kepala Biro Organisasi, Kepala Biro Hukum, Kepala Biro Pemerintahan, Kepala Biro Protokol dan Komunikasi Publik, Kepala Biro Administrasi Pembangunanm kepala Biro Adminitrasi Kesejahteraan Rakyat, dan Kepa Biro Pengadaan Barang dan Jasa. Dimana data ini dikumpul untuk melengkapi data primer, baik yang tersedia di Badan Pusat Statistik, Sekretariat Daerah Provinsi Kalimantan Tengah. Data tesebut diperoleh dengan penelitian terhadap dokumen, laporan, brosur, surat kabar dan bahan kepustakaan lainnya. 


\section{HASIL DAN PEMBAHASAN}

Pemerintah saat ini dengan gencarnya melakukan perubahan struktur, fungsi, finansial, dan personalia dan organisasi birokrasi itu, tetapi sesungguhnya yang terpenting perlu digaris bawahi bahwa perubahan tersebut di atas harus diikuti oleh perubahan budaya organisasi birokrasi dan perilaku manusia-manusia terlibat didalamnya.

Berdirinya suatu Pemerintah Daerah Provinsi Kalimantan Tengah sekarang ini tidak didapatkan dengan mudah melainkan dengan perjuangan para pemuda Kalimantan Tengah pada saat itu. Dengan segenap jiwa dan raga mereka berjuang untuk mengusir para penjajah dari tanah Kalimantan Tengah demi kemerdekaan.

Masyarakat Provinsi Kalimantan Tengah mempunyai tradisi dalam melaksanakan pekerjaan “lebih suka mendahului kebanding didahului” namun hal tersebut diatas belum dapat mempengaruhi atau mewarnai kepada para birokrat pemerintah Provinsi Kalimantan Tengah. Birokrat cenderung masih menunggu perintah atasan baru mau mengerjakan, apabila atasan tidak memberikan perintah langsung maka cenderung para birokrat itu enggan dan lambat untuk melaksanakan tugas-tugas yang sudah jelas termasuk dalam tugas pokok dan fungsi (tupoksi).

Seandainya tradisi tersebut dapat mewarnai para birokrat bahkan menjelma kepada budaya lokal yang ada di birokrasi Sekretariat Daerah Provinsi Kalimantan Tengah tentu dapat menciptakan suasana kerja yang kompetitif dan positif dalam tubuh organisasi pemerintahan. Suka mendahului dalam hal mengerjakan bidang tugas dan dapat semakin berinisiatif dan berinovasi.

$\mathrm{Hal}$ ini juga didukung dengan pendapat saat wawancara dengan Kepala Sub Bagian Kepegawaian di Sekretariat Daerah Provinsi Kalimantan Tengah (21/10/2019) bahwa:

"Kebanyakan para pejabat hanya mau mencari selamat, yakni apabila terjadi kesalahan atau pelanggaran yang terungkap oleh publik atau pimpinan maka sang pejabat tersebut melemparkan kesalahan tersebut kepada bawahannya. Sehingga terkesan sang pejabat mencari selamat sendiri tanpa memikirkan nasib bawahannya. Perilaku yang tidak bertanggung jawab merupakan penyakit menular yang semakin lama menjadi sebuah penyakit (patologis) menurun kepada generasi-generasi muda birokrasi berikutnya".

Apabila perilaku-perilaku yang menyimpang tersebut harus menyebar, maka dapat mengakibatkan kurang kondusifnya suasana kerja di kalangan birokrat dimana ada rasa saling mencurigakan antara atasan dan bawahannya atau bahkan sesama staf.

Budaya birokrasi yang juga digambarkan oleh Kepala Bagian Pengembangan Kinerja Aparatur Pemerintah mengungkapkan bahwa disiplin kerja, loyalitas kepada atasan sangat tinggi dan rendahnya tingkat konflik di tubuh birokrasi itu sendiri. Ini menandakan para birokrat mengambil posisi konservatif. Mereka cenderung menghindar dari perbedaan pendapat dengan atasan karena takut dianggap tidak pro dengan atasan dan tidak terpakai kembali (non job).

Hal tersebut diatas termasuk kepada budaya birokrasi aristokrat. Budaya birokrasi aristokrat dapat mengakibatkan birokrasi kita menjadi tertutup dan kurang memberikan ruang gerak bagi pendapat yang berbeda. Apabila kita melihat kepada Budaya Birokrasi Aristokrat, yang mempunyai ciri-ciri sebagai berikut :

I. Mengkultuskan pribadi pemimpin

2. Lebih banyak berorientasi ke atas

3. Kuatnya kesadaran dan prestise dan status yang melebihi prestasi.

4. Sikap untuk menjaga harmoni dan menghindari konflik.

Sehingga, birokrasi di Sekretariat Daerah Provinsi Kalimantan Tengah termasuk pada ciri budaya birokrasi aristokrat, yaitu sikap untuk menjaga harmoni dan menghindari konflik. 
Budaya birokrasi mampu menetapkan tapal batas untuk membedakan dengan organisasi birokrasi lain, mampu bentuk identitas identitas organisasi, dan identitas kepribadian anggota organisasi, mampu mempermudah terciptanya komitmen yang bersifat kepentingan individu, mampu meningkatkan kemantapan keterikatan sistem sosial dan mampu berfungsi sebagai mekanisme pembuatan makna dan simbol-simbol kendali perilaku para anggota organisasi.

Menurut peneliti budaya birokrasi di Sekretariat Daerah Provinsi Kalimantan Tengah saat ini juga terjebak pada budaya birokrasi statis-mekanis. Sebagian besar birokrat kecenderungan terbiasa hidup dalam suasana yang rutin, tanpa perlu lagi berpikir dan menggunakan nurani atau perasaan, terjebak pada aturan-aturan dan prosedur, kepatuhan yang luar biasa dengan atasan. Pekerjaan bersifat statis tanpa adanya suatu inovasi yang dapat membawa kerja lebih bersifat dinamis. Arus kerja yang demikian dapat membuat organisasi pemerintah menjadi lebih lamban dan kurang responsif terhadap permasalahan sekarang apalagi yang akan terjadi dimasa yang akan datang.

Peneliti melihat fenomena tersebut diatas seperti halnya "Birokrasi Kaku" para birokrat senantiasa bekerja dan menjalankan pekerjaannya sesuai dengan perintah dan petunjuk serta dalam kesehariannya mengerjakan pekerjaan-pekerjaan rutinitas yang diatur dan dikontrol.

Peneliti juga mengamati permasalahan yang ada saat ini di tubuh birokrasi Sekretariat Daerah Provinsi Kalimantan Tengah. Menurut peneliti permasalahan yang cukup mendasar adalah kurangnya rasa memiliki para birokrat terhadap organisasi birokrasi pemerintahan itu sendiri. Peneliti sering sekali mendapati para birokrat itu terlambat masuk kantor dan ironisnya di kantor bukannya langsung bekerja karena sudah terlambat tetapi langsung baca koran dan sambil menikmati secangkir minuman hangat atau pergi untuk mencari sarapan. Apabila mereka mempunyai rasa memiliki terhadap organisasi tesebut tanpa dengan paksaan atupun karena takut pada atasan, mereka bekerja dengan penuh kesadaran dan loyalitas serta kepedulian yang tinggi terhadap organisasi mereka sendiri (organisasi yang menghidupi mereka), maka mereka akan bekerja sungguh-sungguh untuk melakukan yang lebih baik untuk organisasi itu. Perlu kita sadari bahwa organisasi pemerintah merupakan organisasi non-profit (tidak mencari keuntungan), tetapi mengedepankan fungsi pelayanan masyarakat. Organisasi ini bergerak dengan semangat jiwa sosial dan jiwa pengabdian yang tinggi. Hal ini yang sangat perlu disadari betul oleh para birokrat pemerintah.

\section{Hubungan Good Governance Terhadap Budaya Birokrasi}

Isu sentral paradigma good governance ini adalah bagaimana suatu bangsa dapat menciptakan dan memperluas kepercayaan (trust) antar warga, profesi, dan bangsa lain dalam membangun hubungan politik, ekonomi maupun kemasyarakatan. Berbeda dengan pandangan kebanyakan pengamat sosial politik di Tanah Air, pemikiran mengenai trust (dan distrust) dalam paradigma ini erat kaitannya dengan cara para pemimpin politik membangun mekanisme distribusi sumber daya ekonomi, politik, dan kebudayaan yang tersedia di masyarakat.

Permasalahan yang sangat penting untuk diangkat yaitu masalah budaya birokrasi di Sekretariat Daerah Provinsi Kalimantan Tengah. Pemerintahan belum menaruh perhatian yang serius terhadap perubahan budaya birokrasi di Sekretariat Daerah Provinsi Kalimantan Tengah. Ini terlihat pada anggaran Sekretariat Daerah Provinsi Kalimantan Tengah yang belum berpihak pada pembangunan non fisik yaitu budaya SDM itu sendiri. Sebenarnya budaya organisasi amat besar pengaruhnya terhadap keberhasilan dan mati hidup sebuah organisasi.

Berikut ini penulis berusaha memaparkan korelasi atau hubungan good governance terhadap 
budaya orgnisasi birokrasi Sekretariat Daerah Provinsi Kalimantan Tengah :

Tabel I

Matriks Hubungan Good Governance Terhadap Budaya Birokrasi Sekretariat Daerah Provinsi Kalimantan Tengah

\begin{tabular}{|c|l|l|}
\hline No & $\begin{array}{l}\text { GOOD } \\
\text { GOVERNANCE }\end{array}$ & \multicolumn{1}{|c|}{ BUDAYA BIROKRASI } \\
\hline I & Participation & $\begin{array}{l}\text { Budaya asal bapak senang (abs) statis } \\
\text { mekanis memasung kreativitas dan } \\
\text { kebebasan berpendapat/birokrasi yang } \\
\text { masih kaku. }\end{array}$ \\
\hline 2 & Rule of law & $\begin{array}{l}\text { Kekuasaan politik memiliki dampak } \\
\text { yang besar terhadap penegakan } \\
\text { hukum }\end{array}$ \\
\hline 3 & Transparancy & $\begin{array}{l}\text { Keterbukaan masalah keuangan di } \\
\text { sebagian birokrat belum begitu } \\
\text { terbuka, perebutan sumber daya } \\
\text { keuangan masing-masing unit/bagian. }\end{array}$ \\
\hline 5 & Responsiveness & $\begin{array}{l}\text { Birokrasi masih lemah dalam } \\
\text { merespon kebutuhan publik karena } \\
\text { pemerintah terkesan sangat birokratis } \\
\text { dan budaya statis mekanistis. }\end{array}$ \\
\hline 6 & $\begin{array}{l}\text { Consensus of } \\
\text { orientation }\end{array}$ & $\begin{array}{l}\text { Sub-sub budaya di birokrasi sangat } \\
\text { dominan dalam menentukan } \\
\text { kebijakan-kebijakan }\end{array}$ \\
\hline 8 & efficiency & $\begin{array}{l}\text { Birokrasi cenderung menghabiskan } \\
\text { sumber-sumber/ APBD dengan } \\
\text { asumsi tahun depan dianggarkan } \\
\text { kembali dan boros yaitu lebih besar } \\
\text { biaya aparatur dari pada biaya } \\
\text { pembangunan. }\end{array}$ \\
\hline 7 & Equity & $\begin{array}{l}\text { Masih terselubungnya, ada } \\
\text { pengklasifikasian pelayanan terhadap } \\
\text { beberapa golongan masyarakat. }\end{array}$ \\
\hline Accountability & $\begin{array}{l}\text { Birokrasi cenderung memberikan } \\
\text { pertanggung jawaban apabila diminta } \\
\text { bukan karena rasa kesadaran. }\end{array}$ \\
\hline $\begin{array}{l}\text { Kepemimpinan Sekretaris Daerah } \\
\text { Provinsi Kalimantan Tengah tidak } \\
\text { ditunjang oleh birokrat di bawahnya } \\
\text { yang menjalankan kebijakan-kebijakan } \\
\text { pimpinan. }\end{array}$ \\
\hline Strategic vision
\end{tabular}

Sumber : Dioleh Peneliti, 2019.

\section{Analisis Lingkungan Strategis}

Organisasi tanpa adanya visi dan misi seperti rumah tua yang tak berpenghuni, maksudnya bahwa visi dan misi tersebut merupakan jiwa (soul) dari organisasi tersebut. Visi dan misi akan menjadi penerang dan petunjuk arah bagi organisasi dalam mencapai tujuan bersama yang telah ditetapkan.

Visi menurut Bryson (Miftahuddin, 2003:67) sesungguhnya visi memberikan kerangka dasar tentang gambaran kondisi organisasi di masa yang akan datang. Jadi suatu visi merupakan gambaran kondisi yang akan dicapai di masa yang akan datang. Hal ini berarti visi merupakan suatu pikiran yang melampaui realitas sekarang, keadaan yang diciptakan, yang belum pernah ada dan akan diwujudkan oleh seluruh anggota organisasi.

Visi dan misi Sekretariat Provinsi Kalimantan Tengah tidak akan tercapai apabila belum adanya komitmen dan konsistensi aparatur serta belum baiknya budaya birokrasi, maka saya selalu menekankan pada setiap kesempatan kepada seluruh Bagian untuk selalu bekerja sesuai dengan tupoksi dan saling kerja sama antar bagian serta disiplin dan penuh rasa tanggung jawab.

Berikut ini analisis yang dilakukan terhadap faktor-faktor lingkungan eksternal dalam rangka mewujudkan budaya birokrasi di lingkungan Sekretariat Daerah Provinsi Kalimantan Tengah sebagai berikut:

I. Faktor Politik

Arah kebijakan Sekretariat Daerah Provinsi Kalimantan Tengah dalam mewujudkan budaya birokrasi pemerintahan telah tercermin pada Kepala Daerah kita dalam hal ini adalah Gubernur Kalimantan Tengah. Gubernur sangat berkomitmen terhadap pembentukan budaya birokrasi pemerintah yang ideal. Budaya Birokrasi Pemerintahan yang ada saat ini masih sangat perlu ditingkatkan terutama dalam kedisiplinan kerja pegawai dalam masing-masing instansi dan ini membutuhkan suatu proses yang lumayan Panjang. Sehingga dapat dijadikan suatu barometer untuk mengetahui komitmen dan arah kebijakan pemerintah khususnya dalam membentuk suatu budaya birokrasi yang ideal guna terwujudnya good governance.

2. Faktor Sosial

Faktor sosial masyarakat Provinsi Kalimantan Tengah dapat dilihat dari kualitas pendidikan masyarakat. Peningkatan sumber daya manusia saat ini menjadi prioritas pembangunan di Pemerintah Daerah Provinsi Kalimantan Tengah. Dengan sumber daya yang unggul maka proses pembangunan akan lebih mudah. Masyarakat dapat mengerti dan paham arah, tujuan pembangunan di 
Provinsi Kalimantan Tengah dengan semakin sadarnya masyarakat dengan peranan mereka dalam penyelenggaraan pembangunan, pemerintah dapat menjadi lebih leluasa merealisasikan program pembangunan bagi masyarakat. Mereka tau tanpa dukungan aktif masyarakat perjalanan pembangunan akan lamban bahkan justru tidak tercapai dengan maksimal.

Pemerintah Daerah Provinsi Kalimantan Tengah akan sangat sulit melaksanakan pembangunan daerah apabila tingkat pendidikan masyarakatnya tetap rendah. Pola fikir dan wawasan masyarakatnya dalam menterjemahkan visi dan misi pemerintah akan sangat rendah. Proses peningkatan taraf pendidikan bagi masyarakat Provinsi Kalimantan Tengah tidaklah sebentar melainkan ditempuh dengan waktu yang lumayan lama.

Peningkatan sumberdaya aparatur didalam organisasi Sekretariat Daerah Provinsi Kalimantan Tengah yang berwawasan ilmu pengetahuan dan teknologi (IPTEK) serta iman dan takwa (IMTAK) merupakan tujuan dan sasaran guna mendukung kelancaran serta terwujudnya visi dan misi di Sekretariat Daerah Provinsi Kalimantan Tengah.

\section{Faktor Teknologi}

Sekretariat Daerah Provinsi Kalimantan Tengah belum optimal memanfaatkan teknologi dan informasi dalam pelaksanaan kegiatan dan tugas-tugas, untuk mengatasi hal tersebut, maka diperlukan pemanfaatan teknologi informasi antara lain penggunaan komputer dan internet dengan lebih optimal.

Memang tidak dapat dipungkiri bahwa saat ini masyarakat Provinsi Kalimantan Tengah telah merasakan akibat pembangunan daerah yang begitu pesat, jaringan informasi dan komunikasi yang cepat didapat dan dalam kurun waktu yang singkat di Provinsi Kalimantan Tengah telah berdiri gedung-gedung mewah.
Analisis lingkungan internal organisasi guna mengidentifikasi kekuatan dan kelemahan, aspek-aspek yang membantu atau merintangi pencapaian misi organisasi. Oleh karena itu tujuan utama dari pelaksanaan analisis internal ini adalah untuk mendapatkan informasi-informasi mengenai berbagai kelemahan (weakness) yang dimiliki oleh Sekretariat Daerah dalam rangka penataan budaya birokrasi pemerintahan yang ideal, yakni :

I. Manajemen dan Organiasasi

Perencanaan memiliki peran yang sangat penting yaitu dapat menyingkap berbagai kelemahan. Duplikasi usaha, garis wewenang yang tidak jelas, jalur komunikasi yang terlalu panjang, terlalalu lama birokrasi, dan praktek-praktek yang usang tampak dengan jelas apabila dibandingkan budaya organisasi yang sesungguhnya dengan yang diinginkan.

Sistem pengendalian para birokrat saat ini di Sekretariat Daerah Provinsi Kalimantan Tengah adalah dengan mejalankan fungsi absensi disetiap unit-unit kerja. Bentuk pengawasannya sendiri dilakukan oleh para pemimpin di tiap-tiap bagian Sekertariat Daerah.

Problem utama penyakit birokrasi di pemerintahan kita saat ini justru bukan pada gaji atau tunjangan yang kecil, melainkan tidakberlakunya sistem karier dan sistem pengawasan yang jelas. Justru perilaku KKN terbesar berada pada level birokrasi tingkat menengah ke atas yang sudah mendapat tunjangan dan fasilitas yang sangat menggiurkan.

Kapabilitas dan gaya kepemimpinan dalam organisasi manapun merupakan faktor yang sangat menentukan keberhasilan dalam mencapai tujuan organisasi. Kepemimpinan memiliki pangertian yang agak luas, dikarenakan pemimpin dapat memimpin dan menggerakan orang lain tidak perlu didukung oleh landasan hukum, sedangkan seseorang kepala atau seorang pemimpin karena 
mempunyai wewenang yang dilandasi oleh hukum ia mampu memimpin dan menggerakan kelompoknya.

\section{Faktor Personalia}

Pelaksanaan Organisasi Birokrasi Sekretariat Daerah Provinsi Kalimantan Tengah saat ini masih sangat tergantung dengan kualitas pengelolaan personalia. Personalia itu sendiri menjadi tolak ukur kemajuan suatu daerah sekarang dan di masa yang akan datang. Sumber daya aparatur harus terkelola dengan baik dengan memperhatikan pendidikan, pemahaman, kemampuan mengaktualisasikan tugas.

Bahwa Provinsi Kalimantan Tengah telah merancang karier pegawai sesuai dengan kompetensi yang dimiliki pegawai. Tentunya melalui proses penyeleksian dimulai dari pemeriksaan pangkat dan jabatan terakhir pegawai dengan pendidikan serta kinerja yang bersangkutan apakah layak untuk menduduki jabatan yang direkomendasikan.

3. Sistem Informasi

Kemajuan teknologi saat ini, memberikan peluang yang besar bagi Sekretariat Daerah untuk mengembangkan suatu sistem informasi yang memadai, tetapi sangat disayangkan bahwa peluang ini belum bisa dimanfaatkan secara optimal bagi aparatur di Sekretariat Daerah dalam mengelola sistem informasi tersebut.

Peneliti merasa kesulitan pada waktu peneliti meminta data tentang jumlah pegawai yang berada di Sekretariat Daerah, dimana beberapa data masih diolah secara manual. Padahal dengan kemajuan teknologi yang ada saat ini sudah seharusnya file-file sudah tersimpan didalam komputer.

\section{Tabel 2}

Analisis Faktor-faktor Lingkungan Strategis Dalam Rangka Penataan Budaya Birokrasi di Sekretariat Daerah Provinsi Kalimantan Tengah

\begin{tabular}{|c|c|c|c|c|c|}
\hline No & $\begin{array}{l}\text { Lingkungan Internal dan } \\
\text { Eksternal }\end{array}$ & $\mathbf{S}$ & $\mathbf{W}$ & 0 & $\mathbf{T}$ \\
\hline I & 2 & 3 & 4 & 5 & 6 \\
\hline I & $\begin{array}{l}\text { Lingkungan Eksternal } \\
\text { Faktor Politik } \\
\text { a. Era Reformasi dan Demokratisasi } \\
\text { b. Adanya dukungan dari pemerintah } \\
\text { daerah } \\
\text { c. Affilisi partai polit terhadap birokrasi }\end{array}$ & & & $\begin{array}{l}X \\
X\end{array}$ & $x$ \\
\hline II & $\begin{array}{l}\text { Faktor Sosial } \\
\text { a. Lemahnya kontrol publik terhadap } \\
\text { birokrasi } \\
\text { b. Rendahnya kepercayaan publik } \\
\text { dalam pelayanan pemerintah } \\
\text { c. Keberadaan lembaga-lembaga } \\
\text { pendidikan negari/swasta }\end{array}$ & & & $X$ & $x$ \\
\hline III & $\begin{array}{l}\text { Faktor Teknologi } \\
\text { a. Perkembangan jaringan informasi } \\
\text { dan komunikasi } \\
\text { b. Kondisi lemahnya pemanfaatan } \\
\text { kemajuan teknologi }\end{array}$ & & & $X$ & $X$ \\
\hline I & $\begin{array}{l}\text { Lingkungan internal } \\
\text { Faktor Organisasi dan Manajemen } \\
\text { a. Komunikasi yang kurang berjalan } \\
\text { dengan lancar } \\
\text { b. Sistem Perencanaan yang bersifat } \\
\text { luwes } \\
\text { c. Kultur organisasi ststis mekanistis dan } \\
\text { kultur patologis } \\
\text { d. Tradisi lokal yang kurang mewarnai } \\
\text { birokrasi pemerintahan } \\
\text { e. Lemahnya keyakinan birokrat } \\
\text { terhadap sistem karir pegawai } \\
\text { f. Kurang rasa memiliki terhadap } \\
\text { organisasi birokrasi } \\
\text { g. Dukungan dari aparatur } \\
\text { h. Kapabilitas pemimpin relatif baik } \\
\text { i. Gaya kepemimpinan persuasif dan } \\
\text { demokratis } \\
\text { j. Hubungan pimpinan bawahan relatif } \\
\text { baik }\end{array}$ & $\begin{array}{l}x \\
x \\
x \\
x \\
X\end{array}$ & $\mathrm{X}$ & & \\
\hline II & $\begin{array}{l}\text { Faktor Personalia } \\
\text { a. Pendidikan aparatur yang kurang } \\
\text { memadai } \\
\text { b. Pemahaman dan kemampuan } \\
\text { mengaktualisasikan tugas masih } \\
\text { lemah } \\
\text { c. Ketidaksesuaian kemampuan dengan } \\
\text { tugas yang diembannya } \\
\text { d. daya kreatifitas dan inovasi aparatur } \\
\text { yang masih rendah } \\
\text { e. Perencanaan Pengembangan SDM } \\
\text { aparatur belum berdasarkan } \\
\text { analisis kebutuhan } \\
\text { f. Sistem perencanaan dan } \\
\text { pengembangan karier } \\
\text { g. Sistem penghargaan dan sanksi yang } \\
\text { tidak jelas } \\
\text { h. sistem pengawasan dan penegakan } \\
\text { hukum yang masih lemah terhadap }\end{array}$ & & $x$ & & \\
\hline
\end{tabular}




\begin{tabular}{|c|l|c|c|c|c|}
\hline & $\begin{array}{l}\text { para birokrat } \\
\text { i. Lemah dalam tataran praktis } \\
\text { dianggap formalitas belaka } \\
\text { j. Pengisisn jabatan belum berdasarkan } \\
\text { kompetensi jabatan }\end{array}$ & X & & & \\
\hline III & $\begin{array}{l}\text { Faktor Sistem Informasi } \\
\text { a. Belum adanya sistem informasi yang } \\
\text { memadai } \\
\text { b. Rendahnya kemampuan aparatur } \\
\text { mengelolah sistem informasi }\end{array}$ & $\mathrm{X}$ & & \\
\hline
\end{tabular}

Setelah melakukan penyesuaian antara aspekaspek peluang (Opportunities) dan ancama (Threats) dan lingkungan eksternal dengan aspek-aspek kekuatan (Strenght) dan kelemahan (Weaknesses) dari lingkungan internal yang menghasilkan isu-isu strategis, maka selanjutnya dilakukan evaluasi isu-isu tersebut untuk mengetahui sejauh mana tingkat kestrategisan masingmasing. Dalam mengevaluasi isu-isu strategis tersebut, perangkat evaluasi yang digunakan adalah Litmus test. $\mathrm{Hal}$ ini dimaksudkan untuk mengetahui isu strategis yang benar-benar strategis dan berpengaruh besar terhadap pengemban sumber daya aparatur di Sekretariat Daerah Provinsi Kalimantan Tengah.

Adapun evaluasi terhadap tingkat kestrategisan isu-isu yang berhasil di identifikasikan berdasarkan skor masing-masing isu strategis yang ditawarkan melalui tahapan pertanyaan Litmus Test (Bryson, 2003:182) adalah sebagai berikut (tabel terlampir).

Untuk memperjelas makna dari tingkat kestrategisan masing-masing isu tersebut di atas, maka tahap selanjutnya dilakukan rekapitulasi terhadap nilai skor rata-rata dari masing-masing isu yang dievaluasi dengan menggunakan uji Litmus Test.

\section{Tabel 3}

Rekapitulasi Hasil Uji Litmus Test dan Tingkat Kestrategisan Isu-isu Strategis Yang Dihadapi Dalam Rangka Budaya Birokrasi

\begin{tabular}{|c|c|c|}
\hline Isu Strategis & $\begin{array}{l}\text { Skor } \\
\text { Rata- } \\
\text { rata }\end{array}$ & $\begin{array}{l}\text { Tingkat } \\
\text { Prioritas }\end{array}$ \\
\hline I & 2 & 3 \\
\hline $\begin{array}{l}\text { I. Mengembangkan tradisi } \\
\text { lokal menjadi sebuah } \\
\text { budaya lokal yang berfokus } \\
\text { pada perubahan individu } \\
\text { dan kemajuan organisasi }\end{array}$ & 2,77 & $\begin{array}{c}\text { Pertama } \\
\text { (Sangat Strategis) }\end{array}$ \\
\hline $\begin{array}{l}\text { 2. Melakukan pembaharuan } \\
\text { terhadap sistem karir } \\
\text { birokrat yang berlandaskan } \\
\text { nilai komitmen tinggi antara } \\
\text { eksekutif }\end{array}$ & 2,30 & $\begin{array}{c}\text { Kedua } \\
\text { (Sangat Strategis) }\end{array}$ \\
\hline $\begin{array}{l}\text { 3. } \begin{array}{l}\text { Memberikan pelayanan } \\
\text { berbasis Inforasi dan } \\
\text { teknologi }\end{array} \\
\end{array}$ & 2,23 & $\begin{array}{c}\text { Ketiga } \\
\text { (Sangat Strategis) }\end{array}$ \\
\hline 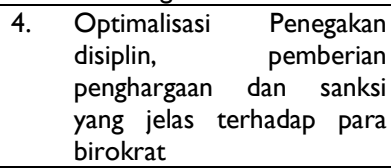 & 2,15 & $\begin{array}{l}\text { Keempat } \\
\text { (Cukup } \\
\text { Strategis) }\end{array}$ \\
\hline $\begin{array}{l}\text { 5. Mengembangkan kualitas } \\
\text { kehidupan kerja }\end{array}$ & 1,85 & $\begin{array}{l}\text { Kelima } \\
\text { (Cukup } \\
\text { Strategis) }\end{array}$ \\
\hline
\end{tabular}

Berdasarkan analisa terhadap lingkungan eksternal dan internal serta berdasarkan analisis SWOT dan Litmus Test, maka didapatkan lima isu strategis untuk Budaya Birokrasi di Sekretariat Daerah Provinsi Kalimantan Tengah, isu-isu strategis tersebut dapat dijadikan rangkaian strategi yang dapat ditetapkan dalam rangka penataan Budaya Birokrasi di Sekretariat Provinsi Kalimantan Tengah:

I. Mengembangkan tradisi lokal yang menjadi sebuah budaya lokal yang berfokus pada perubahan individu dan kemajuan organisasi.

2. Melakukan pembaharuan terhadap sistem karir birokrat yang berlandaskan nilai konsiten dan komitmen tinggi antara eksekutif .

3. Memberikan pelayanan berbasis informasi dan teknologi.

4. Optimalisasi penegakan disiplin, pemberian penghargaan dan sanksi yang jelas.

5. Mengembangkan kualitas kehidupan kerja yang kondusif. 


\section{KESIMPULAN}

Budaya Birokrasi di Sekretariat Daerah Provinsi Kalimantan Tengah dapat disimpulkan bahwa Budaya Birokrasi Pemerintahan di Sekretariat Daerah Provinsi Kalimantan Tengah saat ini masih terjebak ke dalam budaya birokrasi statis mekanistis, budaya birokrasi patologis dan budaya birokrasi aristokrat, sehingga sangat berpengaruh besar terhadap kinerja birokrasi dalam mewujudkan Good Governance.

Strategi yang dapat dilakukan oleh Sekretariat

Daerah Provinsi Kalimantan Tengah dalam mewujudkan budaya birokrasi yang ideal yaitu

I. Mengembangkan tradisi lokal menjadi sebuah budaya lokal yang berfokus pada perubahan individu dan kemajuan organisasi.

2. Melakukan pembaharuan terhadap sistem karir birokrat yang berlandaskan nilai konsisten dan komitmen tinggi antara eksekutif.

3. Memberikan pelayanan berbasis informasi dan teknologi

4. Optimalisasi penegakan disiplin, pemberian penghargaan dan sanksi yang jelas terhadap birokrat.

5. Mengembangkan kualitas kehidupan kerja yang kondusif.

Maka saran yang dapat diberikan oleh peneliti dalam rangka menata budaya birokrasi di Sekretariat Daerah Provinsi Kalimantan Tengah untuk mewujudkan good governance yakni pimpinan organisasi birokrasi untuk mempunyai visi dan misi yang jelas dan dapat menjadi contoh teladan yang baik bagi bawahannya serta memiliki komitmen yang kuat dalam mewujudkan budaya birokrasi yang dibutuhkan organisasi. Dengan terlebih dahulu mendiagnosa budaya yang ada ditubuh birokrasi.

\section{REFERENSI}

Blau, M. Peter dan Meyer, W. Marshall. 2000. Birokrasi

Dalam Masyarakat Modern. PT.Prestasi Pustakakarya. Jakarta.

Brayson, M, Jho. 2007. Perencanaan Strategis Bagi Organisasi Sosial. Pustaka Pelajar. Yogyakarta.

Djatmiko, H Yayat. 2004. Perilaku Organisasi. Alfabeta. Bandung.

Dwiyanto, Agus. 2006, Mewujudkan Good Governance Melalui Pelayanan Publik. Gajah Mada university Press. Yogyakarta.

Gaspersz, Vincent. 2002. Sistem Manajemen Terintegrasi: Balance Scorecard Dengan Six Sigma Untuk Organisasi Bisnis Dan Pemerintah. PT Gramedia Pustaka Utama. Jakarta.

Handoko, T. Hani. 200I. Manajemen Personalia dan Sumber Daya Manusia. BPFE. Yogyakarta.

Rusidi. 2002. Sinopsis Usulan Penelitian. Makalah Kuliah Metodologi Penelitian. Jakarta.

Said, M. Mas'ud. 2007. Birokrasi di Negara Birokratis. UMM Pers. Malang.

Salim, Agus. 2002. Perubahan Sosial. Bumi Aksara. Jakarta.

Sedamayanti. 2007. MSDM Reformasi Birokrasi dan Manajemen Pegawai Negeri Sipil. PT Refika Aditama. Bandung.

Senge, Peter. M. 2002. Disiplin Kelima Seni dan Praktek dari Organisasi Pembelajaran. Alih Bahasa Ir. Nunuk Adiani,MM. Bina Rupa Aksara, Jakarta.

Suwandi, made. 2002. Otonomi dan Keuangan Daerah. Makalah Kuliah Manajemen Keuangan Daerah. IIP. Jakarta.

Thoha, Miftha. 1995. Perspekif Perilaku Birokrasi. Rajawali. Jakarta.

Usmara, A dkk. 2002. Paradigma Baru Manajemen Sumber Daya Manusia. Amara Books. Yogyakarta.

Wasistiono, Sadu. 2003. Kapita Selekta Manajemen Pemerintahan Daerah. Fokusmedia. Bandung. 
Wasistiono, Sadu, dkk. 2002. Manajemen Sumber Daya Aparatur Pemerintah Daerah. Pusat Kajian PemerintahanSTPDN - Fokus Media. Bandung.

Widodo, Joko. 2005. Good Governance Telaah dari Dimensi Akuntabilitas dan Kontrol Birokrasi Pada Era Desentralisasi dan Otonomi Daerah. PT.Insan Cendikia. Surabaya.

Wisnu, Dicky dan Siti Nurhasanah. 2005. Teori Organisasi Struktur dan Desain. Penerbit UMM. Malang. 